\title{
Sexual Harassment and Effect on Students' Self-Esteem in Selected Public and Private Secondary Schools in Kenya
}

\author{
Naom Ondicho $^{1 *}$ Kisilu Kombo ${ }^{2}$ Felicita W. Njuguna ${ }^{3}$ \\ 1. PhD candidate, Department of Educational Management, Policy and Curriculum Studies Kenyatta University \\ PO BOX 43844, Nairobi Kenya. \\ 2. Dean, School of Education, Kenyatta University PO BOX 43844, Nairobi Kenya. \\ 3. Senior Lecturer, Department of Educational Management, Policy and Curriculum Studies Kenyatta University \\ PO BOX 43844, Nairobi Kenya
}

\begin{abstract}
Sexual Harassment (SH) is a global phenomenon and a pervasive problem that affects thousands of students in learning institutions daily yet there are few studies exploring its effect on students' self-esteem especially from the Kenyan context. Sexual harassment is also considered a risk factor for lifelong problems including psychological ill-health and poor self-esteem. The purpose of this study was to describe and explore sexual harassment in and its effect on students' self-esteem. The study was done in selected public and private secondary schools in 2 purposively sampled Counties in Kenya. The study was guided by a theoretical framework based on Finkelhor and Browne's Traumagenic Dynamics Model. The design of the study was descriptive survey targeting 23,659 students, 88 Deputy Principals and 88 Heads of G/C. Samples were obtained through purposive and proportionate simple random sampling. Qualitative and quantitative data were collected using a School Sexual Harassment Questionnaire (SSHQ), the Rosenberg Self-Esteem Scale (RSES), interview and Focus Group Discussion (FGDs) guides. Content validity was determined by seeking expert judgments. Cronbach alpha technique was used to measure the reliability of the research instruments. Quantitative data were analyzed both descriptively and inferentially using the Statistical Package for Social Sciences (SPSS) while qualitative data were analyzed based on emerging themes and presented in narrative and verbatim forms. Findings indicated that verbal sexual harassment had a significant effect on students' self-esteem whereas effects of physical and visual sexual harassment were not statistically significant.
\end{abstract}

Keywords: Sexual harassment, forms, students' self-esteem, effect

DOI: $10.7176 / \mathrm{JEP} / 10-21-06$

Publication date:July $31^{\text {st }} 2019$

\section{Introduction}

It is believed that students face different forms of maltreatment while in school some of which are sexual in nature (Wei \& Chen, 2011). Studies have shown that Sexual Harassment (SH) is prevalent in secondary schools and that this harassment not only affects students' social wellbeing but their psychological health which in turn impacts on their self-esteem (AUUW, 2003, \& 2006; Young, et a., 2008; Hill \& Holly, 2011; UNICEF, 2014; Gruber \& Finneran, 2016; Bendixen et al., 2018). Kenya's Ministry of Education (MOE) defines sexual harassment as unwanted and unwelcome behaviours of a sexual nature that cause discomfort to the targeted person. These behaviours include words, persistent requests for sexual favours, gestures, touch, suggestions, coerced sexual intercourse and rape (MOE, 2001) all of which are risk factors for lifelong problems among students including psychological ill-health and poor self-esteem (Witt et al., 2018, Dahlqvist et al., 2016).

Empirical studies have established that SH is a near epidemic in schools across the globe (Chang, Hayter, \& Lin, 2010). However, many of these studies emanate from the west in countries like the USA, Canada, The Netherlands, China and Australia. Similar studies from the Kenyan context are scanty and where available, they fail to explore the effects of this harassment on the self-esteem of students. Nonetheless, student sexual harassment in Kenya's institutions of learning is not a new phenomenon. In 2018, the Kenyan media reported the rape of three female students in a girls' only boarding school situated a few minutes' drive from the official residence of retired President Moi with whom the school shares a name. The incident which took place inside the washrooms at night at Moi Nairobi Girls Secondary School negatively impacted both the victims and the rest of the student body leading to temporary closure of the school.

In the same year, 2018, at Loreto Msongari Girls in Kiambu County, a female student was forced to change school when she was sexually harassed while she slept. In 2017, a male student was gang raped at Maseno School by form 3 and 4 boys leading to the interdiction of the school principal. In 2016, St. Caritas Mariana mixed Secondary school in Thika West was closed by officials from the MOE and 72 students sent home over allegations of sexual abuse at the school then headed by a Nigerian priest (Citizen Digital, September 5, 2018). There have also been incidents of SH in other renowned secondary schools such as Kakamega Boys School, the former St. Kizito Boys high school in 1990 where 19 students lost their lives and several others left traumatised, Kangubiri Girls in Nyeri in 2006 and at Keveye girls from Western Kenya in 1996. There are, however, indications that the 
actual statistics of sexual harassment in schools may be higher than reported due to the culture of silence that surrounds issues of sex (Idoko, 2016).

Table 1: Schools with Reported Incidents of Sexual Harassment in Kenya

\begin{tabular}{|l|l|l|l|}
\hline School & School type & Year & Magnitude of harassment \\
\hline St Kizito Mixed Sec. school & Public Boarding & 1990 & $\begin{array}{l}\text { Grievous, several students raped, } \\
\text { 19 dead, 71 left traumatised }\end{array}$ \\
\hline Keveye Girls Sec. School & Public Boarding & 1996 & Serious, 12 girls impregnated \\
\hline Kangubiri Girls Sec. School & Public Boarding & 2006 & Serious, 3 students raped \\
\hline $\begin{array}{l}\text { St. Caritas Mariana Mixed Sec. } \\
\text { School }\end{array}$ & Public Day & 2016 & $\begin{array}{l}\text { Serious sexual allegations, school } \\
\text { temporarily closed }\end{array}$ \\
\hline Maseno Boys Sec. School & Public Boarding & 2017 & Serious, student gang raped \\
\hline Kakamega Boys Sec. School & Public Boarding & 2018 & Serious, student sodomised \\
\hline Loreto Convent Msongari & Private Boarding & 2018 & Less grievous, unwanted touches \\
\hline Moi Nairobi Girls Sec. School & Public Boarding & 2018 & Serious, 3 students raped \\
\hline
\end{tabular}

Source: Media/ research reports, Kenya

A study by Ondicho et al. (2019) established that sexual harassment is on an upward trajectory in learning institutions in Kenya. The study which was conducted in selected secondary schools in Nyamira South and Thika West sub counties found that public and private secondary school students were victims of diverse forms of sexual abuses majorly perpetrated by peers and other adults in schools. However, the study like most others before did not look explore the effects of this harassment on the self-esteem of students thus leaving a gap in knowledge which the present study sought to fill.

\subsection{Statement of the Problem}

Even though considered a global phenomenon and a near epidemic in most schools (Chang et al., 2010) there are few studies in the Kenyan context exploring sexual harassment in both public and private secondary schools and its effects on students' self-esteem. The Kenya Demographic and Health Survey (KDHS) observes that until 2003 there was no nationally representative data on sexual violence in Kenya's schools (Maternowska et al., 2009). Much of what is known as sexual violence in schools was gathered from press and media reports. This study sought to establish sexual harassment in selected secondary schools in Nyamira and Kiambu Counties, Kenya and its effects on students' self-esteem.

\section{Conceptual and Theoretical Frameworks}

The present study was guided by a conceptual framework based on the Traumagenic Dynamics Model (TDM) developed in 1985 by David Finkelhor and Angela Browne (Finkelhor \& Browne, 1985). The Model posits that experiences of sexually abused children can be analysed in terms of 4 trauma causing factors: traumatic sexualisation, betrayal, powerlessness and stigmatization (Makhija, 2014). This study considered powerlessness and stigmatization. Powerlessness is marked by fear and low esteem. Further, sexually abusive experiences create disempowerment through sexual messages communicated covertly and overtly. These traumatising experiences undermine a child's self-worth by causing feelings of worthlessness, shamefulness and guilt. The stigmatization factor is linked to a child's level of awareness hence high school students are likely to be more stigmatised than those in lower classes. TDM postulates that the stigmatization factor covers all the mechanisms that undermine children's positive self-image and self-esteem. Omari (2015) opines that demeaning and sexually abusive language is not only hurtful but is also a significant contributor to emotional and psychological problems. 


\section{Independent Variable}

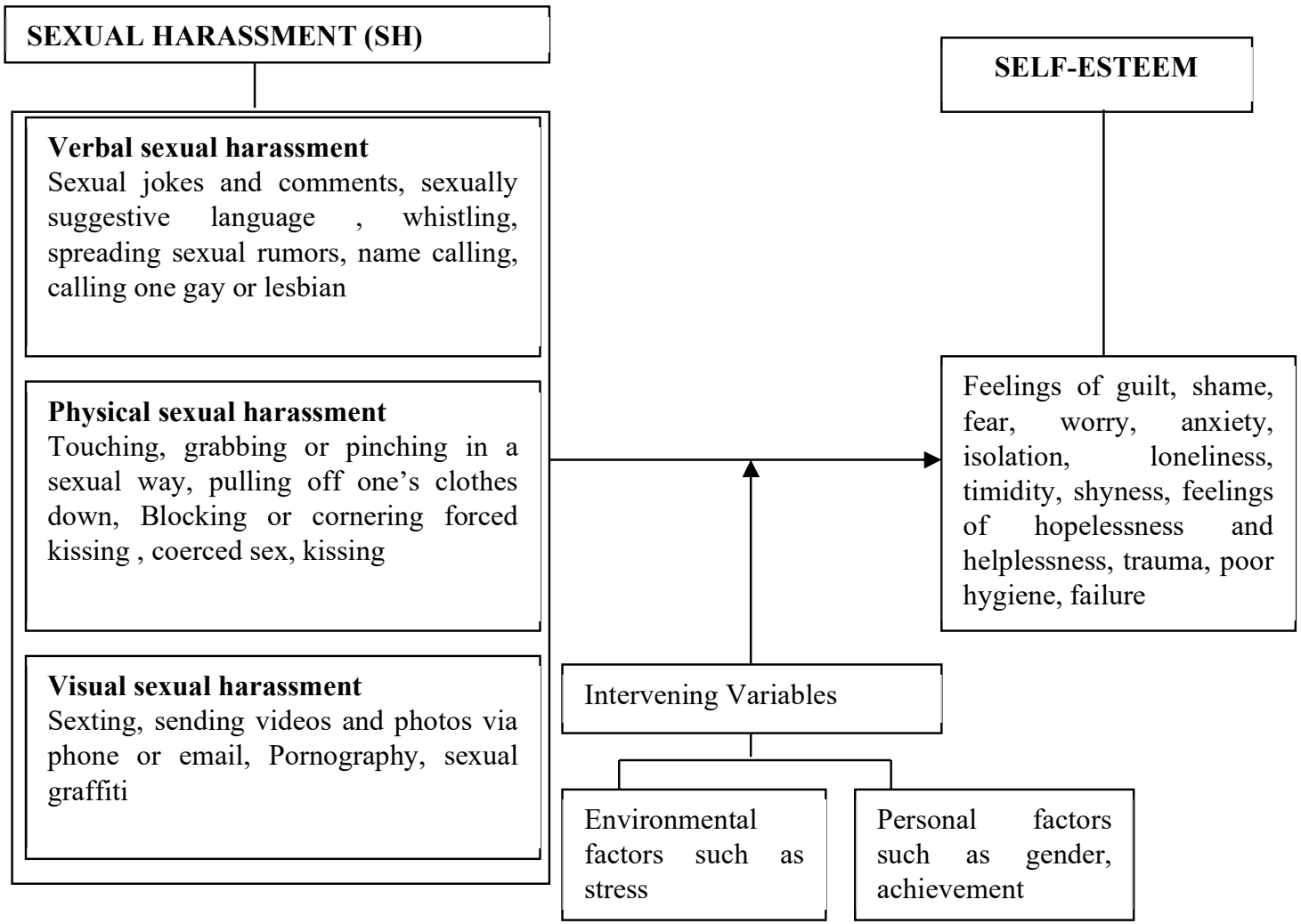

Figure 1.1: Conceptual Framework showing the convergence between sexual harassment and self-esteem Source: Authors

\section{Literature Review}

The United States of America's Department for Education and Civil Rights (2008) describes sexual harassment as unwelcome conducts of a sexual nature. These conducts can be categorized into verbal, physical and visual forms. They include unwelcome sexual advances, requests for sexual favors, unwanted touches, sexual comments, jokes, or gestures; writing graffiti or displaying or distributing sexually explicit drawings, pictures, or written materials; calling students sexually charged names; spreading sexual rumors; rating students on sexual activity or performance; or circulating, showing, or creating e-mails or Web sites with explicit sexual content (AAUW, 2013). These conducts are believed to have debilitating effects on students' self-esteem.

Self-esteem refers to how people feel about themselves, how they perceive their value to the world and how valuable they think they are to others (Strauss, 2012). Self-esteem encompasses beliefs such as competence, triumph, despair, pride and shame. One's self-esteem can either be positive or negative, high or low. Okoko (2012) posits that people with high self-esteem are presumed to be psychologically happy and healthy, they feel good about themselves, are able to cope with challenges and generally lead productive lives. Unfortunately, the presence of sexual harassment in schools destroys this status as it affects students in diverse ways. For instance sexually spiked gossip and rumors can drive students to develop depression and suicidal thoughts, loss of friends and ruined reputations which are indicators of a low-esteem (Gordon, 2017).

Title IX (a law that prevents SH in schools in the USA) recognizes two broad forms of sexual harassment: Quid Pro Quo harassment which occurs whenever a student's participation in an educational program or activity is supposedly pegged on their willingness to submit to a sexual request and hostile environment sexual harassment which typically involves sexual advances, requests for sexual favors, and other verbal, non-verbal, or physical conducts of a sexual nature (AAUW, 2011). The latter is most common in schools.

In middle and high schools in America, over $80 \%$ of students report experiencing varied forms of $\mathrm{SH}$ much of which are perpetrated by peers (AAUW, $2003 \&$ 2012). Whereas some forms of these forms occur rarely and are mild, others occur more frequently and register effects ranging from severe, moderately severe to very severe. Rape, sexual coercion and sexual assault are considered some of the most severe forms of physical sexual harassment (Wane, 2009; Hill \& Holly, 2011). These are not only debilitating, but they also leave victims 
psychologically traumatized and terrified besides eliciting lots of silence and denial (Mwiti, 1997;).

In Britain, Canada, China, Israel, Norway and Germany SH is on an upward trajectory both in and out of secondary schools (Zeira et al., 2002; Canadian Press, 2008; Wei \& Chen, 2011; Bendixen et al., 2018; Witt et al., 2018). In Canada, a survey of 1800 students carried out in 23 high schools showed that over $50 \%$ of girls were victims of unwanted sexual comments and gestures which affected their health, adjustment, worth and overall wellbeing in school (Canadian Press, 2008). In China, a study conducted among Junior high school students revealed that $\mathrm{SH}$ in the form of name calling and rumor mongering was quite prevalent in Chinese schools and that this harassment negatively affected both the perpetrators and the victims (Wei \& Chen, 2011).

Across section of schools in Africa specifically in schools in Ghana, Botswana, Ethiopia, S. Africa, Tanzania, Niger and Uganda reveal that SH forms part of daily school life (www.hrw.org/reports/2001/safrica) which leave students suffering in multiple ways (www.hrw.org/reports/2001/safrica). Bunyi (2003) affirms that this harassment occurring in the form of persistent insulting verbal remarks, physical attacks including rape, sexual assault; forced sexual penetration and other types of Gender Based Violence (GBV) are regularly perpetrated on students.

In 2008, the Government of Kenya through the Ministry of Education (MOE) and in collaboration with the Church World Service Schools (CWSS) came up with a School Standards Safety Manual (SSSM) to protect students against unsafe practices in schools. The SSSM addresses student sexual abuse and recognizes chronic lack of self-esteem and low self-confidence as forms of emotional abuse meted on children. Standard Safety Number 10 of the SSSM urges schools to ensure that learners are safe from physical, emotional and sexual abuse and neglect perpetuated either by fellow learners, teachers, parents or community members. The MOE has also published guidelines and policies such as the Gender Policy in Education which address sexual abuses in schools. Nevertheless, reports of student sexual harassment in schools continue unabated pointing probably to weaknesses in policy implementation.

In effect, schools are supposed to be child friendly providing conducive learning atmospheres where students are protected from all forms of harm. In Child Friendly Schools, (CFSs) students are protected from threats such as rape, physical beating, humiliation, sexual harassment, taunts from fellow students and even physical hazards such as pollution, noise, fires and unhygienic environments. The aim of this study was to determine the forms of sexual harassment prevalent in secondary schools in Kenya and their effects on students' self-esteem.

\section{Design and Methodology}

The study adopted a descriptive survey research design embracing qualitative and quantitative methods of data collection and analysis. The study was located in Nyamira South and Thika West sub counties. Nyamira South is one of the five administrative Sub Counties in Nyamira County. This County is found in one of the most densely populated regions in Kenya: Nyanza region posted a total of 5,824,711 people in the 2009 National Housing and Population Census. The County is served with high density schools with a big student population. Majority of the inhabitants of Nyamira County are of the Abagusii tribe who are patriarchal by nature (Johnstone, 2002). Thika West is one of the ten Sub Counties that make up Kiambu County which is situated in the Central region of Kenya with a total population of 744,010 inhabitants. . It covers an area of $1,324 \mathrm{~km}^{2}$. Majority of the inhabitants are of the Kikuyu tribe who are matriarchal in nature.

The schools were first stratified into public and private secondary schools and then into single sex and mixed schools. Proportionate simple random sampling was used to arrive at the required sample size of 3 girls' only, 3 boys' only and 11 mixed secondary schools. A School Sexual Harassment Questionnaire (SSHQ) was used to collect data from a randomly selected sample of 380 students (105 girls and 80 boys) obtained through the Krejcie and Morgan (1970) Table of Sample Size Determination. Study participants were sampled across forms 1 to 3. Form four students were left out intentionally as they were considered too busy preparing for end of cycle national exam.

Data triangulation was done through interviewing key informants: Deputy Principals and Guidance and Counseling (G\&C) Coordinators) representing the 8 sampled schools. The study observed confidentiality, anonymity and freedom of participation. Quantitative data collected were analyzed using SPPS and presented in frequencies, percentages and tables while qualitative data were analyzed based on emerging themes and presented in narratives and in the voices of the informants.

\section{Findings and Discussions}

The study targeted 88 secondary schools with a total student population of 12,594 students $(6,288$ boys \& 6,306 girls). Half of the participating schools (50.0\%) were mixed secondary schools and the rest were single sex schools ( $25.0 \%$ girls' only and $25.0 \%$ boys' only). The demographic characteristics of the sample respondents are summarized on table 1 . 
Table 1: Demographic Characteristics of Respondents

\begin{tabular}{|l|l|l|}
\hline Variable & Frequency (F) & Percentage (\%) \\
\hline Gender & & \\
Boys & 80 & $43.0 \%$ \\
Girls & 105 & $56.8 \%$ \\
\hline Class & & \\
Form 1 & 69 & $37.3 \%$ \\
Form 2 & 50 & $27.0 \%$ \\
Form 3 & 66 & $35.7 \%$ \\
\hline Religion & & \\
Christian & 170 & $97.7 \%$ \\
Muslim & 2 & $1.1 \%$ \\
Other & 2 & $1.1 \%$ \\
\hline Age & & \\
14 years & 23 & $11.9 \%$ \\
15 years & 62 & $32.1 \%$ \\
16 years & 29 & $15.0 \%$ \\
17 years & 58 & $30.1 \%$ \\
18 years & 15 & $7.8 \%$ \\
Over 18 years & 6 & $3.1 \%$ \\
\hline
\end{tabular}

Table 1 shows that there were $56.8 \%$ female and $43 \%$ male respondents in the study. Slightly more than $37 \%$ of these respondents were form ones. The mean age of the respondents was 15 years. The data shows that $6(3.1 \%)$ students were above 18 years old surpassing the ideal age of high schools students in Kenya which is between 1418 years. It is important to note that the free and subsidized education initiative started in 2013 has over the years attracted back to schools students who are sometimes much older than the other students in the classes they are enrolled in. The table similarly shows that $97 \%$ of the students were Christians, $2 \%$ were Muslims and $2 \%$ indicated that they belonged to other religions. This finding is a fair representation of the Kenyan populace where majority are professed Christians and few are Muslims. The rest belong to several other religious and nonreligious groupings.

Table 2 shows the forms of SH witnessed and or experienced by students in secondary schools in the study locale.

Table 2: Prevalent Forms of Sexual Harassment

\begin{tabular}{lll} 
& \multicolumn{2}{c}{ Students' views } \\
& F & \% \\
\hline Verbal sexual harassment & 141 & $40.3 \%$ \\
Physical sexual harassment & 125 & $35.7 \%$ \\
Visual sexual harassment & 84 & $24.0 \%$ \\
\hline
\end{tabular}

The findings on table 2 show that of the three forms of sexual harassment either experienced or witnessed in secondary schools in the selected study locale, verbal sexual harassment was the most prevalent form ( $40.3 \%)$. This form of harassment manifests itself in the form of sexual rumours, use of obscene, dirty or vulgar language, use of sexually suggestive names such as 'sweetie', Baibe' as well as use of gestures that are sexually suggestive. It encompasses asking or being asked for sexual favours either by fellow students or adults within the school and whistling and ogling at others in a sexually suggestive manner. The findings demonstrate that physical sexual harassment was the second most prevalent whereas the least prevalent form of sexual harassment in secondary schools was visual sexual harassment.

Next the researcher sought to measure students' self-esteem. The results are as shown on table 3 . 
Table 3: Students' Self-Esteem Scores

\begin{tabular}{llll}
\hline Scores & F & \% \\
\hline 14.00 & 2 & .5 \\
16.00 & 2 & .5 \\
17.00 & 2 & .5 \\
18.00 & 6 & 2.0 \\
19.00 & 11 & 2.7 \\
20.00 & 10 & 2.5 \\
21.00 & 22 & 5.4 \\
22.00 & 38 & 9.4 \\
23.00 & 47 & 11.6 \\
24.00 & 38 & 9.4 \\
25.00 & 63 & 15.6 \\
26.00 & 27 & 6.7 \\
27.00 & 22 & 5.4 \\
28.00 & 24 & 5.9 \\
29.00 & 11 & 2.7 \\
30.00 & 15 & 3.7 \\
31.00 & 5 & 1.2 \\
\hline
\end{tabular}

It is evident from table 3 that 167(48.7\%) students scored above 25 hence demonstrating that their self-esteem was high and 176(51.3\%) students obtained scores below 25 hence were considered to be having low self-esteem. The mean self-esteem score using 343 students who fully responded to all the items on the scale was 20.5 showing that majority of the students in this specific sample had low self-esteem. Overall there were more students with low self-esteem $235(58.6 \%)$ than high self-esteem $166(41.4 \%)$ in both public and private schools.

Table 4: Students' Self-esteem* Category of School

\begin{tabular}{lccc}
\hline Category of school & $\begin{array}{l}\text { Students' Self-esteem } \\
\text { Low Self-Esteem }\end{array}$ & High Self-Esteem & Total \\
\hline Public schools & $205(87.2 \%)$ & $146(88.0 \%)$ & $351(87.5 \%)$ \\
Private schools & $30(12.8 \%)$ & $20(12.0 \%)$ & $50(12.5 \%)$ \\
\hline Total & $235(58.6 \%)$ & $166(41.4 \%)$ & $401(100 \%)$ \\
\hline
\end{tabular}

Chi-square $\left(\chi^{2}=0.046, \mathrm{df}=1 \quad p<0.05\left(\right.\right.$ Critical $\chi^{2}=3.84$ at $\left.p<0.05\right)$

The results of the cross tabulation between student self-esteem levels and category of school as shown on table 4.15 reveal that there were more students with low self-esteem 235(58.6\%) than high self-esteem 166(41.4\%) in both public and private schools. Results of $\chi^{2}=0.046$ at 0.05 level of significance showed that there was a statistically significant relationship between public and private secondary schools and students' self-esteem levels. Eremie and Chikweru (2015) found significant differences between public and private school students' self-esteem scores which they attributed to differences in socio-economic factors and the school learning environment.

Table 5: Verbal Sexual Harassment * Students' Self-esteem

\begin{tabular}{|c|c|c|c|c|c|c|c|}
\hline \multicolumn{8}{|c|}{ Students' Self-esteem } \\
\hline & & & $\begin{array}{l}\text { Strongly } \\
\text { disagree }\end{array}$ & Disagree & Agree & $\begin{array}{l}\text { Strongly } \\
\text { agree }\end{array}$ & Total \\
\hline \multirow{10}{*}{$\begin{array}{l}\text { Verbal } \\
\text { harassment }\end{array}$} & \multirow[t]{10}{*}{ sexual } & Large extent & 1 & 14 & 51 & 4 & 70 \\
\hline & & & $25.0 \%$ & $32.6 \%$ & $18.8 \%$ & $19.0 \%$ & $20.6 \%$ \\
\hline & & Moderate & 1 & 12 & 135 & 7 & 155 \\
\hline & & extent & $25.0 \%$ & $27.9 \%$ & $49.8 \%$ & $33.3 \%$ & $45.7 \%$ \\
\hline & & Small extent & 0 & 8 & 60 & 6 & 74 \\
\hline & & & $0.0 \%$ & $18.6 \%$ & $22.1 \%$ & $28.6 \%$ & $21.8 \%$ \\
\hline & & Not at all & 2 & 9 & 25 & 4 & 40 \\
\hline & & & $50.0 \%$ & $20.9 \%$ & $9.2 \%$ & $19.0 \%$ & $11.8 \%$ \\
\hline & & Total & 4 & 43 & 271 & 21 & 339 \\
\hline & & & $100.0 \%$ & $100.0 \%$ & $100.0 \%$ & $100.0 \%$ & $100.0 \%$ \\
\hline
\end{tabular}

Chi-square $\left(\chi^{2}=20.48, \mathrm{df}=9 \quad p<0.05\left(\right.\right.$ Critical $\chi^{2}=16.92$ at $\left.p<0.05\right)$

Table shows that a combined total of $186(78.6 \%)$ students said that verbal sexual harassment affected their self-esteem from a moderate to a large extent whereas a combined 28(8.3\%) students either strongly disagreed or disagreed that verbal sexual harassment affected self-esteem from a moderate to a large extent. Less than $10 \%$ of students indicated that verbal sexual harassment did not have any effect at all on their self-esteem contrary to the view of the majority. This means that in general in one way or the other verbal sexual harassment affected the selfesteem of a student. 
Informants expressed diverse feelings connected to different forms of verbal sexual harassment. One student said thus:

I don't like it when I am told I have sexy eyes. I really don't understand what that means. It hurts me.

Another student said:

I always get these verbal remarks by boys saying 'you are cute', 'I admire your hips'....I don't like these remarks at all. Then there are endless cat calls whenever I passed. I don't think this kind. I feel uncomfortable.

A male student expressed dislike over what he considered a verbally insulting remark directed at him:

It is insulting to be told you have the looks of a girl. Is that right? I don't think so.

For some students however the verbal sexual harassment made them indifferent and quite unsure whether the comments made them feel bad or good. One student stated:

I am always receiving these funny comments from my class mates. They tell me I have an attractive body for men. Often I don't take them seriously. I know they are joking. I am really not sure how that makes feel, partly good and sometimes bad. But I think it should now stop.

These sentiments from the students indicate the upsetting nature of verbal sexual harassment and its negative effects on their esteem. Sometimes the verbal sexual comments may be mild but when said repeatedly may cumulatively affect a student's self-esteem.

Table 6: Physical Sexual Harassment and Students' Self-Esteem

\begin{tabular}{|c|c|c|c|c|c|c|c|}
\hline & & & Students & eem & & & \\
\hline & & & $\begin{array}{l}\text { Strongly } \\
\text { disagree }\end{array}$ & Disagree & Agree & $\begin{array}{l}\text { Strongly } \\
\text { agree }\end{array}$ & Total \\
\hline Physical & Sexual & Large extent & 0 & 7 & 64 & 6 & 77 \\
\hline harassment & & & $0.0 \%$ & $16.7 \%$ & $23.6 \%$ & $30.0 \%$ & $22.8 \%$ \\
\hline & & Moderate & 0 & 9 & 69 & 3 & 81 \\
\hline & & extent & $0.0 \%$ & $21.4 \%$ & $25.5 \%$ & $15.0 \%$ & $24.0 \%$ \\
\hline & & Small extent & 1 & 16 & 98 & 5 & 120 \\
\hline & & & $25.0 \%$ & $38.1 \%$ & $36.2 \%$ & $25.0 \%$ & $35.6 \%$ \\
\hline & & Not at all & 3 & 10 & 40 & 6 & 59 \\
\hline & & & $75.0 \%$ & $23.8 \%$ & $14.8 \%$ & $30.0 \%$ & $17.5 \%$ \\
\hline Total & & & 4 & 42 & 271 & 20 & 337 \\
\hline & & & $100.0 \%$ & $100.0 \%$ & $100.0 \%$ & $100.0 \%$ & $100.0 \%$ \\
\hline
\end{tabular}

Chi-square $\chi^{2}=16.43, \mathrm{df}=9 \mathrm{p}<0.05($ Critical $=16.92 \mathrm{p}<0.05)$

It is evident from the results on table 4.18 that $70(53.6 \%)$ of the student respondents combined either strongly agreed or agreed that physical sexual harassment affected their self-esteem to a large extent. The results also indicate that $69(25.5 \%)$ students were of the view that physical sexual harassment affected their esteem to a moderate extent and 98(36.2\%) students to a small extent. Based on the obtained scores of the $\chi^{2}$ value, the study concluded that there was no statistically significant relationship between physical sexual harassment and students' self-esteem. The finding of no significant relationship between physical sexual harassment and students' selfesteem went contrary to the expectations. One would expect that unwanted and inappropriate touching; grabbing and pinching someone, physically forcing someone into having sex with them or kissing, hugging, touching them against their wish would affect students in one way or the other yet chi-square results from the analyzed findings failed to demonstrate this relationship.

Table 7: Visual Sexual Harassment* and Students' Self-Esteem

\begin{tabular}{|c|c|c|c|c|c|c|c|}
\hline & & & Students & eem & & & \\
\hline & & & $\begin{array}{l}\text { Strongly } \\
\text { disagree }\end{array}$ & Disagree & Agree & $\begin{array}{l}\text { Strongly } \\
\text { agree }\end{array}$ & Total \\
\hline Visual & Sexual & Large extent & 0 & 11 & 69 & 7 & 87 \\
\hline harassment & & & $0.0 \%$ & $26.2 \%$ & $25.8 \%$ & $36.8 \%$ & $26.2 \%$ \\
\hline & & Moderate & 0 & 14 & 85 & 4 & 103 \\
\hline & & extent & $0.0 \%$ & $33.3 \%$ & $31.8 \%$ & $21.1 \%$ & $31.0 \%$ \\
\hline & & Small extent & 1 & 4 & 56 & 2 & 63 \\
\hline & & & $25.0 \%$ & $9.5 \%$ & $21.0 \%$ & $10.5 \%$ & $19.0 \%$ \\
\hline & & Not at all & 3 & 13 & 57 & 6 & 79 \\
\hline & & & $75.0 \%$ & $31.0 \%$ & $21.3 \%$ & $31.6 \%$ & $23.8 \%$ \\
\hline Total & & & 4 & 42 & 267 & 19 & 332 \\
\hline & & & $100.0 \%$ & $100.0 \%$ & $100.0 \%$ & $100.0 \%$ & $100.0 \%$ \\
\hline
\end{tabular}

Chi-square $\chi^{2}=13.658, \mathrm{df}=9 \mathrm{p}<0.05($ Critical $=16.92 \mathrm{p}<0.05)$

From table 7 , it is clear that regardless of the extent students experienced or witnessed visual sexual harassment, majority of the students $103(31.0 \%)$ either strongly agreed or agreed with the fact that visual sexual 
harassment affected their self-esteem to a moderate extent. The number of students who indicated that visual harassment affected them to a large extent was lower at $26.2 \%$ (87). The findings show that $29(8.7 \%)$ students disagreed that visual sexual harassment affected their self-esteem from a small extent to a large extent. Interestingly, 63(22.6\%) students expressed the view that visual harassment did not affect their self-esteem at all. The calculated chi-square value $\left(\chi^{2}=13.66, \mathrm{df}=9 \mathrm{p}=0.05\right)$ was interpreted against the chi-square table value of 16.92. Based on the figures, the study concluded that there was no statistically significant relationship between visual sexual harassment and effect on students' self-esteem. The probable reason could be that whereas there is generally lots of sexually harassing incidents in the environment yet some incidents may be rare within the school setting due to presence of rules and regulations which bar their manifestation. Some of the schools in the study sample were categorical regarding the use of electronic gadgets in their schools. It is through the use of some of these gadgets that visually harassing content is sometimes sent to a non-willing recipient. One key respondent said:

We have clear rules in school. Our students are not allowed to come with mobile phones to school. We inspect them when they report back to school during school opening days and when they come back from mid-term break. we also conduct impromptu searches of their things both in the dorm and in class and any student found with a phone is punished...

Another student said:

In our school, electronic items such as mobile phones are not allowed.

The ban of mobile phones in schools withstanding, some key informants were of the view that the same could be used during holidays when access was not if access was not restricted. Another probable reason why visual harassment was least prevalent may be tied to censorship by some schools of materials they stock in their libraries and computers which are only of academic nature.

\section{Conclusion}

Based on the findings, it can be concluded that sexual harassment of diverse forms is a common occurrence in public and private secondary schools in Kenya. This harassment affects both boys and girls and takes place in all types of schools. The findings demonstrate that sexual harassment has an effect on student self-esteem. The findings moreover indicate that students from private secondary schools were more likely to have higher esteem levels when compared to students from public secondary schools. Consequently, sexual harassment has a greater negative effect on the self-esteem of students from public schools that private. These findings demonstrate the need for concerted stakeholder support to deal with issues of SH in secondary schools.

\section{References}

American Association of University Women (AAUW) (1993). Hostile hallways: The AAUW survey on sexual harassment in America's schools. Washington, D.C. USA.

AAUW. (2001). Hostile hallways: Bullying, teasing and sexual harassment in school. Washington D.C. USA.

AAUW. (2002). Hostile hallways: Bullying, teasing and sexual harassment in school. Washington D.C. USA.

AAUW. (2006). Drawing the line: Sexual harassment on campus. Washington D.C. USA.

AAUW. (2011). Crossing the line. Sexual harassment at school. Washington D.C. USA

Bendixen, M., Daveroni, J. \& Kennair, L. E. O. (2018). The effects of non-physical peer sexual harassment on high school students' psychological well-being in Norway: Consistent and stable findings across studies. International Journal of Public Health, 63, 3-11 https://doi.org/10.1007/s00038-017-1049-3.

Canadian Press. (2015). Sexual harassment in Canada. The Canadian Press, 13 February, 2015.

Canadian Press. (2008). Sexual harassment, bullying par for the course in Ontario high Schools:

Survey: Feb 07, 2008.

Chang, Y., Hayter, M., \& Lin, M. (2010). Experiences of sexual harassment among elementary schools students in Taiwan: Implications for school nurses. Journal article. https://doi.org./19.1177/1059840509355585. accessed 8/8/2018.

Citizen TV news reporter. (2018, June 2). www.citizentvnews.co.ke

Dunne, M., Bosumtwi-Sam, C., Sabates, R., \& Owusu, A. (2010). Bullying and school attendance: A case study of high schools in Ghana. Research Monograph No. 41.

Gruber, J., \& Fineran, S. (2007). The impact of bullying and sexual harassment on health outcomes of middle school and high school girls. Violence against Women, 13(2), 627 - 643

Hill, C. \& Holly, K. A. M. (2011). Crossing the line. Sexual harassment at school. AAUW, Washington D.C. USA

Hussin, J.H (2015). Sexual harassment in the workplace: An exploratory study from Lebanon. Journal of Management Research, 7 (1), 107-121.

Idoko, P., Ngane, S. N., \& Ogbe, E.A. (2015). Sexual harassment in urban secondary schools in the Gambia. The International Journal of Medical and Applied Sciences, 4 (11), 3112-3137.

Krejcie, R.V., \& Morgan, D.W. (1970) Determining sample size for research activities. Educational and 
Psychological Measurement, 30, 607-10.

Larkin, J. (1997). Sexual harassment: High school girls speak out. Ontario: Ontario Canada Second Story Press.

Makewa, L. N., Role, E., \& Ngila, W. M. (2014). Girl child challenges and academic achievement in mixed secondary schools. Journal of Education and Human Development, 3 (2), 471-491.

Maternowska, C., Keesbury, J., \& Kilonzo, N. (2009). Sexual violence: Setting the research agenda for Kenya. Nairobi: Population Council.

Menkel, E., \& Witkowska (2005). Perceptions of sexual harassment in Swedish high schools: Experiences and school environment problems. European Journal of Public Health, 15(1), 78-85.

Meursing, K. et al. (1995). Child sexual abuse in Matabele land. Zimbabwe Journal of Social Sciences and Medicine, 41 (12), 1693-1704.

MOE (2008). Safety standards manual for schools in Kenya (1 st ed.). Nairobi, Kenya: Government Printer.

MOE (2010). What is sexual harassment? Nairobi, Kenya: Ministry of Education.

MOE (2017). Gender policy in education. Nairobi: Republic of Kenya.

Mwiti, G. K. (2006). Child abuse. Nairobi, Kenya: Evangel Publishing House.

Ondicho, N. K., Njuguna, F.W., \& Kombo, K. (2019). Prevalence of Students' Sexual Harassment in Secondary Schools in Nyamira and Kiambu Counties, Kenya. Researchjournali's Journal of Education, Vol. 7 | No. 3 March | 2019 ISSN 2347-8225.

Rinehart, S., Doshi, N., \& Espelage, D. (2016). Sexual harassment and sexual violence experience among Middle School Youth. University of Illinois at Urbana-Champaign

Robinson, K. (2000) Great Tits, Miss! The silencing of male students' sexual harassment of female teachers in secondary schools. A focus on gender authority. Discourse on studies in the cultural politics of education, 21 (1), 351-365.

Ruto, S. J. (2009). Sexual abuse of school age children: Evidence from Kenya. Journal of International Cooperation in Education, 12 (1), 177-192.

Smit, D., \& Plessis, D.U. (2011). Sexual harassment in the education sector. http/dx.doi.org/10.4314/pel.v1416.6. Teachers' Service Commission (2010). Protection of pupils/students from sexual abuse. TSC circular No 3/2010.

Terrance, C., Logan, A., \& Peters, D. (2004). Perceptions of peer sexual harassment among high school students. Journal of Sex Roles, 51 (7/8), 328-351.

UNICEF (2004). Update of the situation assessment and analysis: Children's and women's rights in Nigeria. UNICEF: Abuja.

UNICEF (2016). Violence against children in education settings in South Asia. A desk review.

UNICEF, Regional Office for South Asia (ROSA).

Wachira, K. (2018, June 10). How safe are our girls in schools? The Saturday Nation. P. 13. Retrieved from http://www.nation.co.ke/News

Wane, N. (2009). Sexual violence and HIV/AIDS risks in Kenyan \& Ugandan schools: Social 4(1), http://ejournals.library.ualberta.ca/index.php/JCIE

Wei, H., \& Chen, J. (2011). Factors associated with peer sexual harassment victimization among Taiwanese adolescents. Sex Roles, 66-78.

Witt, A., Rassenhofer, M., Brahler, A. E., Plener, P. L., \& Fegert, J.M. (2018). The prevalence of sexual abuse in institutions: Results from population-based sample in Germany. https://doi.org/10.1177/1079063218759323.

World Health Organization, WHO. (2002). World report on violence and health, Geneva: World Health Organization.

World Health Organization, WHO. (2008). World report on violence and health. Chapter 6: Sexual violence. Geneva: World Health Organization.

\section{Acknowledgements}

I wish to thank the National Council for Science and Research (NACOSTI)in Kenya for issuing the needed permit that allowed this research to take place and to the deputy school principals, the Coordinators of Guidance and Counseling, the teachers and all students from the selected public and private secondary schools in Nyamira and Kiambu Counties who willing participated in this study. Special thanks to the late Stephen Ondicho and Judy Gitau who were very helpful in data collection and data analysis respectfully.

\section{Compliance with Ethical Standards}

This study was conducted after obtaining clearance and written approval from the Kenyatta University Ethics Committee.

Naom Ondicho is pursuing doctoral studies in education management at Kenyatta University, Kenya under the academic supervision of Dr. Felistas Njuguna and Prof. Kisilu Kombo. Naom is a trainer in a public Technical and Vocational Training Institute (TVET). Prior to joining the TVET sector she taught in secondary schools within the capital city of Nairobi. Her research interests are on Leadership and Education management, Gender and Gender 
Based Violence, Children and Youth, Life skills Education and Mentorship.

Prof. Kisiilu Kombo is an associate professor and the current serving Dean of School of Education, Kenyatta University. He holds a doctorate degree in Sociology of Education of Kenyatta University.. Prof. Kombo has vast experience in University teaching, research and supervision, extensive field work and involvement in community work and service. He has carried out many researches, co-authored many books and published in refereed journals. Prof. has a wide knowledge of sociological issues affecting the society. His interests are in conducting social science research on education-related matters, community development, mentorship and administration.

Dr. Felicita Wanjiru Njuguna holds a PhD in Educational Social Psychology from Jawaharlal Nehru (JNU) University (JNU) New Delhi, India. She is a senior lecturer in Education Management, Policy and Curriculum studies Department, Kenyatta University where she teaches and supervises undergraduate and postgraduate students. Dr. Njuguna has held several leadership posts within the university management setup. She is the chair of Muranga County Education Board to date besides serving as an Education Expert Committee Member in Kenya National Commission for UNESCO. She is the current chair of the Board of Women Education Researchers of Kenya (WERK) and an active member Forum for African Women Educationalists, Kenya Chapter (FAWEK). She has researched widely in Education. She is an Alumnus of University of Nairobi in Kenya. 